\title{
IMPLEMENTASI MODEL LEARNING CYCLE “5E" DISERTAI LKS UNTUK MENINGKATKAN AKTIVITAS, KETERAMPILAN PROSES SAINS, DAN HASIL BELAJAR BIOLOGI
}

\author{
Ahmad Purwanto \\ Pendidikan Biologi FKIP Universitas Muhammadiyah Metro \\ E-mail: biozone_ahmad@yahoo.com
}

\begin{abstract}
This research aims to implement the model learning cycle "5E" accompanied by worksheets to increase activity, science process skills and student learning outcomes. This model provides student involvement and hands-on experience for students, develop a collaborative manner with the group and share your knowledge with other students. Conclusions of this study is the implementation model of learning cycle "5E" with worksheets may enhance the activity, science process skills, and student learning outcomes of $X_{8}$ in the second semester at senior high school $4^{\text {th }}$ Metro on academic year 2011/2012. The increase can be observed as follows: the activity of reading the literature by 23\%, experiment activity (drawing objects of observation) by $25 \%$, in a group discussion activity by $23 \%$, the activity of asking questions by $17 \%$, and argues activity by $10 \%$. In the process skills of science students on aspects of the skill increased by $25 \%$ using the tool, the object classifies 30\%, the cooperation within the group by $22 \%$, delivering the acquisition of 23\%. Learning outcomes of students has increased by $4 \%$ which is in cycle I of $71 \%$ to $75 \%$ in cycle II. As for the improvement of pre-survey to cycle II by 56\% which is $19 \%$ in pre-survey become to $75 \%$ in Cycle II.
\end{abstract}

Kata kunci: model learning cycle " $5 E$ " disertai LKS, aktivitas belajar, keterampilan proses sains, hasil belajar

$\begin{array}{lllr}\text { Pembelajaran sains (biologi) } & \text { media pembelajaran serta sistem } \\ \text { sebagai bagian dari pendidikan, } & \text { pembelajaran yang tepat agar dapat } \\ \text { umumnya memiliki peranan penting } & \text { meningkatkan pengetahuan peserta didik } \\ \text { dalam peningkatan mutu pendidikan, } & \text { serta dapat bersaing dalam menanggapi } \\ \text { khususnya dalam menghasilkan peserta } & \text { perkembangan sains tersebut. } \\ \text { didik yang berkualitas yaitu manusia } & \text { Pembelajaran biologi idealnya } \\ \text { yang mampu bertindak, berpikir kritis, } & \text { menekankan pada aktivitas belajar dan } \\ \text { kreatif, logis, dan berinisiatif dalam } & \text { pemberian pengalaman belajar secara } \\ \text { menanggapi isu di masyarakat yang } & \text { langsung dengan mengembangkan } \\ \text { diakibatkan oleh dampak perkembangan } & \text { keterampilan proses sains agar peserta } \\ \text { sains. Pesatnya perkembangan ilmu } & \text { didik dapat menjelajahi dan memahami } \\ \text { pengetahuan dan teknologi tersebut } & \text { alam. Selain itu penggunaan dan } \\ \text { termasuk ilmu biologi membawa } & \text { pengembangan keterampilan proses } \\ \text { dampak pemilihan materi, metode, dan sains dan sikap ilmiah dalam }\end{array}$


pembelajaran biologi bertujuan agar peserta didik mampu memahami konsepkonsep dan mampu memecahkan masalah biologi dalam sains lingkungan teknologi dan masyarakat (salingtemas).

Mengetahui kondisi riil yang terjadi di lapangan, berdasarkan hasil survei di kelas $\mathrm{X}_{8}$ SMA Negeri 4 Metro pembelajaran biologi yang telah dilaksanakan sudah baik dan perlu dipertahankan tetapi ada juga yang masih kurang dan perlu peningkatan. Hal yang sudah baik dan perlu dipertahankan adalah telah bervariasinya media pembelajaran yang digunakan guru. Hal yang sudah baik tetapi perlu ditingkatkan adalah penggunaan model pembelajaran karena meskipun model pembelajaran yang digunakan guru sudah bervariasi tetapi selama pembelajaran hanya sebagian peserta didik yang aktif mengikuti proses pembelajaran. Dan yang perlu ditingkatkan lebih giat kembali adalah keterampilan proses sains peserta didik karena hasil survei terlihat bahwa guru sudah berupaya dalam melatih semua aspek keterampilan proses sains pada siswanya namun hasilnya masih belum mencapai optimal. Keterampilan proses sains sebagian siswa terlihat belum menguasai aspekaspek dari keterampilan proses sains yang telah ditentukan. Beberapa aspek yang peneliti amati yaitu aspek pengamatan (observasi), aspek klasifikasi (mengelompokan), dan aspek mengkomunikasikan terhadap suatu gagasan maupun kejadian dalam sains lingkungan teknologi dan masyarakat (salingtemas). Hal tersebut merupakan permasalah yang harus dipecahkan.

Sehubungan dengan beberapa komponen yang telah diungkapkan di atas, berdampak pula pada rendahnya persentase hasil belajar biologi siswa yang mencapai KKM dengan skor KKM $=73$.
Dari tabel terlihat bahwa sebagian besar siswa belum mencapai KKM dalam pembelajaran biologi. Siswa yang belum mencapai KKM merupakan suatu permasalahan yang harus dipecahkan. Oleh sebab itu, perlu adanya suatu solusi untuk memecahkan permasalah ini.

Mengetahui kondisi tersebut peneliti dengan guru merencanakan solusi dan tindakan untuk menyelesaikan permasalahan tersebut. Dari hasil kesepakatan bersama antara peneliti dan guru bidang studi biologi dalam penelitian ini, sebagai subjeknya adalah siswa kelas $\mathrm{X}_{8}$ yang diharapkan meningkatnya aktivitas, keterampilan proses sains, dan hasil belajar biologi peserta didik. Maka model yang akan digunakan yaitu learning cycle " $5 E$ " disertai LKS.

Siklus belajar (learning cycle) adalah suatu model pembelajaran yang berpusat pada siswa (student centered). LC merupakan rangkaian tahap-tahap kegiatan (fase) yang diorganisasi sedemikian rupa sehingga siswa berperan aktif untuk dapat menguasai kompetensi-kompetensi yang harus dicapai dalam tujuan pembelajaran. Fajorah (dalam Suastika, 2011) menyatakan "model learning cycle pertama kali diperkenalkan oleh Robert Carplus dalam Science Curriculum Improvement Study (SCIS) USA".

Berikut merupakan penjelasan dari masing-masing tahapan (fase) learning cycle " $5 E$ " :

1. Fase engagement (mengajak) bertujuan untuk membangkitkan minat dan keingintahuan siswa untuk membuat prediksi-prediksi tentang fenomena yang akan dipelajari dan dibuktikan dalam tahap eksplorasi

2. Fase exploration (menyelidiki) memberi kesempatan untuk siswa bekerja baik secara mandiri maupun kelompok tanpa pengajaran langsung dari guru untuk menguji prediksi, 
melakukan dan mencacat pengamatan serta ide-ide melalui kegiatan-kegiatan seperti praktikum dan telaah literatur.

3. Fase explanation (menjelaskan) Fase yang didalamnya berisi ajakan atau mendorong siswa untuk menjelaskan konsep dengan kalimat sendiri, meminta bukti dan klarifikasi dari penjelasan siswa, dan mengarahkan kegiatan diskusi

4. Fase elaboration (mengembangkan) fase didalamnya mengarahkan siswa menerapkan konsep-konsep yang telah dipahami dan keterampilan yang telah dimiliki kedalam situasi baru

5. Fase evaluation (menilai) fase ini bertujuan untuk mengetahui efektifitas tahap-tahap sebelumnya dan pengetahuan serta pemahaman konsep siswa

Menurut Gachy (2011) keunggulan dan kelemahan dari model siklus belajar ini yaitu:

Keunggulan:

1. Membantu mengembangkan sikap ilmiah pebelajar.

2. Meningkatkan motivasi belajar karena pebelajar dilibatkan secara aktif dalam proses pembelajaran.

3. Pembelajaran menjadi lebih bermakna.

Kelemahan:

1. Efektifitas pembelajaran rendah jika guru kurang menguasai materi dan langkah-langkah pembelajaran.

2. Menuntut kesungguhan dan kreativitas guru dalam merancang dan melaksanakan proses pembelajaran.

3. Memerlukan pengelolaan kelas yang lebih terencana dan terorganisasi.

4. Memerlukan waktu dan tenaga yang lebih banyak dalam menyusun rencana dan melaksanakan pembelajaran.
Sebagai alat bantu pemahaman konsep dalam pembelajaran biologi, peneliti menggunakan LKS sebagai sarana pengembangan konsep dalam proses pembelajaran biologi di kelas $\mathrm{X}_{8}$ karena memuat berupa informasi maupun soal-soal (pertanyaanpertanyaan) yang harus dijawab oleh peserta didik sehingga menggalakkan keterlibatan peserta didik dalam belajar. Depdikbud (dalam Annonimus, 2011) menyatakan LKS adalah salah satu media pembelajaran yang didalamnya memuat judul kegiatan, tujuan, daftar nilai, dan bahan yang digunakan dalam kegiatan guna menunjang kebetulan konsep, tugas yang berhubunga dengan kegiatan dan konsep yang digunakan dalam pembelajaran

Belajar adalah berbuat dan sekaligus merupakan proses yang membuat anak didik harus aktif. Menurut Sardiman (2006:95) bahwa: "Pada prinsipnya belajar adalah berbuat. Berbuat untuk mengubah tingkah laku menjadi melakukan kegiatan. Tidak ada belajar kalau tidak ada aktivitas.

Dari pendapat tersebut belajar dapat dipandang sebagai perubahan tingkah laku pada diri siswa seperti perubahan pengetahuan, pemahaman, sikap dan kemampuan mewujudkan proses yang khas untuk mendorong mengorganisirkan aktivitasnya. Oleh karena itu, belajar merupakan bagian dari aktivitas.

Keterlibatan dalam belajar akan memunculkan sebuah keterampilan diantarnya teknik pengembangan keterampilan-keterampilan intelektual, sosial, dan fisik yang bersumber dari kemampuan-kemampuan mendasar yang telah ada dalam diri siswa yang disebut keterampilan proses sains.

Keterampilan proses perlu dikembangkan melalui pengalamanpengalaman langsung sebagai pengalaman pembelajaran. Melalui 
pengalaman langsung seseorang dapat lebih menghayati proses atau kegiatan yang sedang dilakukan. Aspek-aspek kemampuan yang dikembangkan dalam keterampilan proses sains dalam adalah: mengamati, mengelompokan,menafsirkan/interpretas i, meramalkan, mengajukan pertanyaan, berhipotesis, merencanakan percobaan, menggunakan alat atau bahan, menerapkan konsep dan berkomunikasi. Berikut ini disajikan jenis-jenis indikator keterampilan proses sains beserta sub indikatornya (Rustaman; 2005).

Dengan adanya aktivitas belajar yang tinggi dan bekal pengamalan dari keterampilan proses sains siswa dalam belajar harapan secara tidak langsung akan meningkatkan hasil belajar siswa. Menurut Sudjana (2007) hasil belajar adalah kemampuan yang dimiliki siswa setelah ia menerima pengalaman belajarnya. Hasil belajar oleh Bloom diklasifikasikan ke dalam tiga domain (ranah) yaitu ranah kognitif, afektif, dan psikomotorik (wahyono;2000). Bloom membagi masing-masing ranah ke dalam berbagai tingkatan-tingkatan kategori sebagai berikut:

1) Ranah kognitif adalah ranah yang mencakup kegiatan mental (otak). Dalam ranah kognitif terdapat enam jenjang proses berpikir, keenam jenjang tersebut adalah pengetahuan/hafalan/ingatan (C1), pemahaman (C2), penerapan/aplikasi (C3), analisis (C4) sintesis (C5) evaluasi (C6)

2) Ranah afektif adalah ranah yang berkaitan dengan sikap, minat, perhatian, emosi, penghargaan, proses internalisasi, dan pembentuk karakteristik diri.

3) Ranah psikomotorik adalah ranah yang berkaitan dengan keterampilan (skill) dan kemampuan bertindak individu.
Demikian, tujuan dari penelitian ini adalah untuk meningkatkan aktivitas, keterampilan proses sains, dan hasil belajar biologi siswa kelas $\mathrm{X}_{8}$ SMA Negeri 4 Metro melalui model learning cycle " $5 E$ " disertai LKS.

\section{METODE}

Penelitian ini merupakan penelitian tindakan kelas yang dilaksanakan pada semester genap tahun pelajaran 2011/2012 pada siswa SMA Negeri 4 Metro pada standar kompetensi memahami manfaat keanekaragaman hayati, dengan kompetensi dasar siswa mampu mendeskripsikan ciri-ciri filum dalam dunia hewan dan peranannya bagi kehidupan. Penelitian tindakan kelas ini dilaksanakan dalam 2 siklus yang meliputi tahap-tahap dalam penelitian yaitu : 1) perencanaan, 2) pelaksanaan tindakan, 3) observasi dan evaluasi tindakan, dan 4) refleksi dari perjalanan setiap pertemuan yang dilaksanakan selama pembelajaran. Pembelajaran dilaksanakan selama 6 kali pertemuan dengan alokasi waktu setiap pertemuan (2 x 45 menit) sedangkan penelitian dilaksanakan mulai tanggal 05 April sampai dengan 30 April 2012. Penelitian dilaksanakan di SMA Negeri 4 Metro pada semester genap tahun pelajaran 2011/2012 dengan subjek penelitian siswa $\mathrm{X}_{8}$ dengan jumlah siswa 33 siswa dengan tingkat kemampuan yang beragam. Sedangkan objek penelitian meningkatkan aktivitas, keterampilan proses sains dan hasil belajar biologi siswa.

Dalam penelitian, peneliti melakukan tahap penelitian dengan mengkaji materi yang akan dilakukan selama pembelajaran dalam penelitian, setelah itu, menyusun Rencana Pelaksanaan Pembelajaran (RPP), menyusun Lembar Kegiatan Siswa (LKS), mempersiapkan lembar observasi, mempersiapkan alat pembelajaran (spidol, penghapus, buku 
panduan) dan alat-alat yang digunakan pada kegiatan pembelajaran, menyusun alat evaluasi pembelajaran. Dalam tahap pelaksanaan, peneliti melaksanaan pembelajaran dengan model learning cycle " $5 E$ " disertai LKS untuk meningkatkan aktivitas, keterampilan proses sains dan hasil belajar biologi siswa. Dengan langkah-langkah sebagai berikut:

1) Guru menjelaskan kepada siswa tentang tujuan pembelajaran yang akan dilaksanakan dengan model learning cycle " $5 E$ " disertai LKS.

2) Guru memotivasi siswa dengan menginformasikan kaitan materi yang dibahas dengan realita kehidupan pada tahapan engagement

3) Guru memberikan apersepsi sesuai dengan materi yang akan dibahas dengan mengajukan pertanyaan dan mendatangkan jawaban sehingga membuka apa yang diketahui siswa mengenai konsep.

4) Guru meminta siswa untuk berkelompok secara heterogen

5) Guru membagikan LKS serta memberikan penjelasan singkat materi bahasan dan prosedur pelaksanaan pengamatan (observasi)

6) Guru meminta siswa untuk bekerja tanpa langsung pengajaran dari guru yaitu dengan melakukan pengamatan sesuai ketentuan petunjuk dalam LKS pada tahapan exploration.
7) Membimbing siswa saat melakukan kegiatan pengamatan

8) Guru membantu siswa memahami hasil pengamatan dan pertanyaan yang muncul dari pengamatan.

9) Guru meminta siswa menjelaskan apa yang mereka lihat dan memberikan penjelasan mengapa hal tersebut terjadi pada tahapan explanation

10) Guru memperkenalkan penjelasan ilmiah melalui pengajaran formal dan langsung. Guru menghubungkan penjelasan ilmiah dengan bukti fisik dan exploration dan engagement serta menghubungkan penjelasan yang diberikan oleh siswa.

11) Guru meminta siswa untuk menerapkan atau memperluas konsep keterampilan dalam situasi baru pada tahapan elaboration.

12) Memberikan evaluasi pembelajaran kepada siswa untuk dikerjakan secara individu.

Pada tahap terakhir adalah refleksi dilakukan pada setiap akhir pertemuan dan akhir siklus dalam menkaji pembelajaran yang dilakukan.

Tindakan penelitian dikatakan berhasil apabila persentase setiap aktivitas belajar dan keterampilan proses sains siswa telah mencapai target. Adapun target aktivitas belajar dan keterampilan proses sains siswa yang akan dicapai dalam penelitian ini dapat dilihat pada Tabel 2 dan 3 .

Tabel 2. Target Keberhasilan Aktivitas Belajar

\begin{tabular}{|l|l|l|}
\hline No. & Aktivitas Belajar & Persentase \\
\hline 1. & Aktivitas membaca buku pedoman & $\begin{array}{l}\geq 60 \% \text { dari jumlah siswa telah melakukan aktivitas } \\
\text { membaca buku pedoman }\end{array}$ \\
\hline 2. & Berpraktikum (menggambar objek) & $\begin{array}{l}\geq 70 \% \text { dari jumlah siswa telah melakukan aktivitas } \\
\text { berpraktikum (menggambar objek) }\end{array}$ \\
\hline 3. & Berdiskusi dalam kelompok & $\begin{array}{l}\geq 70 \% \text { dari jumlah siswa telah melakukan aktivitas } \\
\text { berdiskusi dalam kelompok }\end{array}$ \\
\hline 4. & $\begin{array}{l}\text { Mengajukan pertanyaan kepada guru } \\
\text { maupun teman }\end{array}$ & $\begin{array}{l}\text { mengajukan pertanyaan kepada guru maupun teman } \\
\text { menatan }\end{array}$ \\
\hline 5. & Mengajukan pendapat & $\begin{array}{l}\text { mengajukan jumlah siswa telah melakukan aktivitas } \\
\text { menganan }\end{array}$ \\
\hline
\end{tabular}


Sedangkan hasil belajar target keberhasilan minimal $70 \%$ dari jumlah siswa mencapai KKM yang telah ditetapkan. Dalam hal ini KKM yang dimaksud yaitu $\geq 73$.
HASIL

Peningkatan aktivitas, keterampilan proses sains dan hasil belajar siswa kelas $\mathrm{X}_{8}$ semester genap SMA Negeri 4 Metro Tahun Pelajaran 2011/2012 pada materi pokok dunia hewan dapat dilihat pada Tabel 4 dan 5.

Tabel 3. Target Keberhasilan Keterampilan Proses Sains

\begin{tabular}{|l|l|l|}
\hline No. & Keterampilan Proses Sains & Persentase \\
\hline 1. & Keterampilan menggunakan alat & $\begin{array}{l}\geq 70 \% \text { siswa menguasai keterampilan } \\
\text { menggunakan alat }\end{array}$ \\
\hline 2. & Keterampilan mengklasifikasikan objek & $\begin{array}{l}\geq 70 \% \text { siswa menguasai keterampilan } \\
\text { mengklasifikasikan objek }\end{array}$ \\
\hline 3. & Kerjasama dalam kelompok & $\begin{array}{l}\geq 70 \% \text { siswa menguasai keterampilan kolaborasi } \\
\text { kerja sama dengan kelompok }\end{array}$ \\
\hline 4. & Keterampilan menyampaikan perolehan & $\begin{array}{l}\geq 70 \% \text { siswa menguasai keterampilan } \\
\text { menyampaikan prolehannya. }\end{array}$ \\
\hline
\end{tabular}

Tabel 4. Data Peningkatan Aktivitas Belajar Siswa.

\begin{tabular}{|c|c|c|c|c|c|}
\hline \multirow[b]{2}{*}{ No. } & \multirow[b]{2}{*}{ Jenis Aktivitas } & \multicolumn{3}{|c|}{ Persentase } & \multirow{2}{*}{$\begin{array}{c}\text { Peningkatan } \\
\text { Prasurvei- } \\
\text { Siklus II }\end{array}$} \\
\hline & & Prasurvei & Siklus I & Siklus II & \\
\hline 1 & Aktivitas membaca buku pedoman & $45 \%$ & $57 \%$ & $68 \%$ & $23 \%$ \\
\hline 2 & Berpraktikum (menggambar objek) & $60 \%$ & $79 \%$ & $85 \%$ & $25 \%$ \\
\hline 3 & Berdiskusi dalam kelompok & $60 \%$ & $69 \%$ & $83 \%$ & $23 \%$ \\
\hline 4 & $\begin{array}{l}\text { Mengajukan pertanyaan kepada guru maupun } \\
\text { teman }\end{array}$ & $30 \%$ & $36 \%$ & $47 \%$ & $17 \%$ \\
\hline 5 & Mengajukan pendapat & $20 \%$ & $23 \%$ & $30 \%$ & $10 \%$ \\
\hline
\end{tabular}

Tabel 5. Data Peningkatan Keterampilan Proses Sains siswa.

\begin{tabular}{|c|c|c|c|c|c|}
\hline \multirow[b]{2}{*}{ No } & \multirow[b]{2}{*}{ Jenis Keterampilan } & \multicolumn{3}{|c|}{ Presentase } & \multirow{2}{*}{$\begin{array}{c}\text { Peningkatan } \\
\text { Prasurvei- } \\
\text { Siklus II }\end{array}$} \\
\hline & & Prasurvei & Siklus I & Siklus II & \\
\hline 1 & Keterampilan menggunakan alat & $50 \%$ & $75 \%$ & $75 \%$ & $+25 \%$ \\
\hline 2 & Keterampilan mengklasifikasikan objek & $40 \%$ & $65 \%$ & $70 \%$ & $+30 \%$ \\
\hline 3 & Kerjasama dalam kelompok & $50 \%$ & $69 \%$ & $72 \%$ & $+22 \%$ \\
\hline 4 & Keterampilan menyampaikan perolehan & $50 \%$ & $72 \%$ & $73 \%$ & $+23 \%$ \\
\hline
\end{tabular}

Tabel 6. Data Peningkatan Hasil Belajar Siswa.

\begin{tabular}{|c|c|l|c|c|c|c|}
\hline No. & Nilai & \multicolumn{1}{|c|}{ Kategori } & Prasurvei & Siklus I & Siklus II & $\begin{array}{c}\text { Peningkatan } \\
\text { Prasurvei- } \\
\text { Siklus II }\end{array}$ \\
\hline 1 & $\geq 73$ & Mencapai KKM & $19 \%$ & $71 \%$ & $75 \%$ & $56 \%$ \\
\hline 2 & $<73$ & Belum Mencapai KKM & $81 \%$ & $29 \%$ & $25 \%$ & - \\
\hline
\end{tabular}




\section{PEMBAHASAN}

\section{Aktivitas Belajar Siswa}

Pada penelitian ini pembelajaran biologi menggunakan model learning cycle " $5 E$ " disertai LKS. Aktivitas siswa menjadi indikator dalam penelitian telah mengalami perubahan dari persentase hasil prasurvei ke siklus II 45\% dari 33 siswa aktivitas membaca buku pedoman meningkat menjadi 68, aktivitas berpraktikum (menggambar objek) dari $60 \%$ meningkat menjadi $85 \%$, aktivitas berdiskusi dalam kelompok dari 60\% meningkat menjadi 83\%, aktivitas mengajukan pertanyaan kepada guru maupun teman 30\% meningkat menjadi $47 \%$, dan aktivitas menajukan pendapat dari 20\% meningkat menjadi 30\%.

Aktivitas siswa dalam kegiatan pembelajaran ini yang lebih dominan adalah membaca dan berpraktikum (menggambar objek) yang termasuk dalam tahap eksplorasi. Siswa melakukan percobaan dan pengamatan yang disajikan dalam LKS. Aktivitas siswa yang juga dominan adalah berdiskusi dengan kelompok dalam tahap penjelasan (explanation). Hal ini menunjukkan bahwa siswa antusias ingin mengetahui lebih jelas tentang materi yang dipelajari yang sudah didapat dari kegiatan LKS yang dilakukan pada tahap eksplorasi dan ekplanasi. Pernyataan tersebut didukung oleh Suastika (2011) menyatakan "Aktivitas siswa dalam model learning cycle " $5 E$ " yang lebih dominan adalah membaca dan mengerjakan LKS yang termasuk dalam tahap eksplorasi. Siswa melakukan percobaan, pengamatan yang disajikan dalam LKS serta berdiskusi dengan teman sebaya”.

\section{Keterampilan Proses Sains Siswa}

Peningkatan keterampilan proses

sains dapat terukur melalui rubik penilaian yang mencangkup kriteriakriteria pada Tabel 7.

Berdasarkan kriteria penilaian KPS tersebut, maka peningkatan keterampilan proses sains siswa kelas $\mathrm{X}_{8}$ dapat dilihat dari siklus I yaitu keterampilan menggunakan alat memiliki persentase paling tinggi yaitu mencapai 75\% dengan kategori baik, keterampilan mengklasifikasikan objek memiliki persentase 65\% termasuk kategori baik. Pada keterampilan kerjasama dalam kelompok memiliki persentase 69\% dengan kategori baik. Sedangkan keterampilan menyampaikan perolehan memiliki persentase $72 \%$ dengan kategori baik. Dan mengalami peningkatan pada siklus II yaituk eterampilan menggunakan alat mencapai 75\%, termasuk kategori baik, pada keterampilan mengklasifikasikan objek mencapai 70\% termasuk kategori baik, keterampilan kerjasama kelompok mencapai $72 \%$ termasuk kategori sangat baik, serta keterampilan menyampaikan perolehan mencapai $73 \%$ dengan kategori baik

Seperti yang diungkapkan Gachy (2011) keunggulan dari model learning cycle " $5 E$ " ini adalah membantu mengembangkan sikap ilmiah pebelajar, meningkatkan motivasi belajar karena pebelajar dilibatkan secara aktif dalam proses pembelajaran sehingga siswa dapat bekerja sama, saling belajar, keakraban, saling menghargai, partisipasi, kemampuan berbahasa peserta didik, lebih berpeluang untuk menyampaikan pendapat dan gagasan. Keterampilan-keterampilan tersebut dikembangkan oleh siswa dalam masingmasing setiap tahapan model learning cycle " $5 E$ " yang disertai LKS.yaitu pada tahapan. 
Tabel 7. Kriteria Penilaian Keterampilan Proses Sains

\begin{tabular}{|c|c|c|c|c|c|}
\hline KPS & $\begin{array}{l}\text { Sangat baik } \\
(81-100)\end{array}$ & $\begin{array}{l}\text { Baik } \\
(61-80)\end{array}$ & $\begin{array}{l}\text { Cukup } \\
(41-60)\end{array}$ & $\begin{array}{l}\text { Kurang } \\
(21-40)\end{array}$ & $\begin{array}{l}\text { Sangat kurang } \\
(0-20)\end{array}$ \\
\hline 1 & $\begin{array}{l}\text { Lincah, tepat, } \\
\text { tidak } \\
\text { memerlukan } \\
\text { bantuan }\end{array}$ & $\begin{array}{l}\text { Kurang lincah, } \\
\text { tepat , tidak } \\
\text { memerlukan } \\
\text { bantuan }\end{array}$ & $\begin{array}{l}\text { Kurang lincah, } \\
\text { kurang tepat, } \\
\text { sedikit } \\
\text { memerlukan } \\
\text { bantuan }\end{array}$ & $\begin{array}{l}\text { Tidak lincah, } \\
\text { kurang tepat, } \\
\text { banyak } \\
\text { memerlukan } \\
\text { bantuan }\end{array}$ & $\begin{array}{l}\text { Tidak memilih, } \\
\text { merangkai, dan } \\
\text { mengoprasikan } \\
\text { alat. }\end{array}$ \\
\hline 2 & $\begin{array}{l}\text { Dengan cepat } \\
\text { menentukan dan } \\
\text { membedakan } \\
\text { secara luas ciri- } \\
\text { ciri objek secara } \\
\text { tepat, tidak } \\
\text { memerlukan } \\
\text { bantuan }\end{array}$ & $\begin{array}{l}\text { Kurang cepat } \\
\text { menentukan dan } \\
\text { membedakan } \\
\text { beberapa ciri- } \\
\text { ciri objek } \\
\text { namun tepat, } \\
\text { tidak } \\
\text { memerlukan } \\
\text { bantuan }\end{array}$ & $\begin{array}{l}\text { Kurang cepat } \\
\text { menentukan dan } \\
\text { membedakan } \\
\text { beberapa ciri-ciri } \\
\text { objek namun } \\
\text { kurang tepat, } \\
\text { sedikit } \\
\text { memerlukan } \\
\text { bantuan }\end{array}$ & $\begin{array}{l}\text { Tidak cepat } \\
\text { menentukan dan } \\
\text { membedakan ciri- } \\
\text { ciri objek namum } \\
\text { kurang tepat, } \\
\text { banyak } \\
\text { memerlukan } \\
\text { bantuan }\end{array}$ & $\begin{array}{l}\text { Tidak dapat } \\
\text { menentukan dan } \\
\text { membedakan } \\
\text { ciri-ciri objek }\end{array}$ \\
\hline 3 & $\begin{array}{l}\text { Aktif kerjasama } \\
\text { dalam } \\
\text { kelompoknya, } \\
\text { memberi } \\
\text { pendapat dan } \\
\text { menanggapi } \\
\text { pendapat dalam } \\
\text { kelompoknya } \\
\text { dengan tepat }\end{array}$ & $\begin{array}{l}\text { Kurang aktif } \\
\text { kerjasama } \\
\text { dalam } \\
\text { kelompoknya, } \\
\text { memberi } \\
\text { pendapat dan } \\
\text { menanggapi } \\
\text { pendapat dalam } \\
\text { kelompoknya } \\
\text { dengan tepat }\end{array}$ & $\begin{array}{l}\text { Kurang aktif } \\
\text { kerjasama dalam } \\
\text { kelompoknya, } \\
\text { memberi pendapat } \\
\text { dan tidak } \\
\text { menanggapi } \\
\text { pendapat dalam } \\
\text { kelompoknya }\end{array}$ & $\begin{array}{l}\text { Kurang aktif } \\
\text { kerjasama dalam } \\
\text { kelompoknya, } \\
\text { tidak memberi } \\
\text { pendapat dan } \\
\text { tidak menanggapi } \\
\text { pendapat dalam } \\
\text { kelompoknya }\end{array}$ & $\begin{array}{l}\text { Tidak } \\
\text { bekerjasama } \\
\text { dalam } \\
\text { kelompoknya, } \\
\text { tidak memberi } \\
\text { pendapat dan } \\
\text { tidak } \\
\text { menanggapi } \\
\text { pendapat dalam } \\
\text { kelompoknya }\end{array}$ \\
\hline 4 & $\begin{array}{l}\text { Tampak } \\
\text { memahami } \\
\text { konsep } \\
\text { berdasarkan } \\
\text { perolehan dan } \\
\text { menyampaikan } \\
\text { dengan tepat }\end{array}$ & $\begin{array}{l}\text { Kurang } \\
\text { memahami } \\
\text { konsep } \\
\text { berdasarkan } \\
\text { perolehan dan } \\
\text { menyampaikan } \\
\text { dengan tepat }\end{array}$ & $\begin{array}{l}\text { Kurang } \\
\text { memahami } \\
\text { konsep } \\
\text { berdasarkan } \\
\text { perolehan dan } \\
\text { menyampaikan } \\
\text { kurang tepat }\end{array}$ & $\begin{array}{l}\text { Tidak memahami } \\
\text { konsep } \\
\text { berdasarkan } \\
\text { perolehan dan } \\
\text { menyampaikan } \\
\text { kurang tepat }\end{array}$ & $\begin{array}{l}\text { Tidak } \\
\text { memahami } \\
\text { konsep } \\
\text { berdasarkan } \\
\text { perolehan dan } \\
\text { tidak } \\
\text { menyampaikan } \\
\text { perolehan }\end{array}$ \\
\hline
\end{tabular}

Keterangan:

KPS: 1 Keterampilan menggunakan alat

KPS: 2 Keterampilan mengklasifikasikan objek

KPS: 3 Keterampilan kerjasama dalam kelompok

KPS: 4 Ketrampilan menyampaikan perolehan

Tabel 8. Skala Kategori Kemampuan

\begin{tabular}{|c|c|}
\hline Nilai (\%) & Kategori Kemampuan \\
\hline $81-100$ & Sangat Baik \\
$61-80$ & Baik \\
$41-60$ & Cukup \\
$21-40$ & Kurang \\
$<20$ & Sangat Kurang \\
\hline
\end{tabular}

(Riduwan, 2005:18)

Pada fase engagement dilakukan pembangkitan minat belajar siswa dengan memunculkan pertanyaan yang berkaitan dengan dunia hewan. Misalnya tahukan anda struktur tubuh dari cacing tanah dan peranan cacing tanah bagi kehidupan manusia? mengacu potensi siswa untuk berfikir terhadap ilmu pengetahuan yang akan dikaji, sehingga minat belajar siswa lebih berantusias. Tahapan selanjutnya exploration, pada tahapan ini keterampilan dalam mengungkap pengetahuan yang ada di dalam objek pengamatan siswa dapat 
berkembang serta dibantu adanya LKS. Keterampilan menggunakan alat yang dimaksud adalah keterampilan siswa dalam menggunakan alat-alat laboratorium selama kegiatan pengamatan berlangsung, baik alat-alat laboratorium maupun alat indera seperti indera penglihatan, indera penciuman, indera peraba yang dioptimalkan untuk memperoleh data hasil pengamatan seperti ciri, karakteristik, struktur maupun sifat dari suatu objek biologi yang dalah hal ini berbagai hewan tak bertulang belakang dan hewan bertulang belakang diantaranya hewan tak bertulang belakang yaitu Annelida, Mollusca, Arthropoda, jenis hewan bertulang belakang seperti hewan-hewan Pisces dan Amphibia. Dalam tahapan ini menunjukan siswa dapat mengoptimalkan kemampuan yang telah mereka miliki baik fisik maupun mental, serta kemampuan tersebut telah dikembangkan siswa secara berkelanjutan dalam kehidupan seharihari. Hal tersebut seperti yang diungkapkan oleh Holil (2008) bahwa kemampuan mendasar yang telah dikembangkan dan terlatih lamakelamaan akan menjadi suatu keterampilan.

Selain itu, pada tahapan ini nampak adanya kerja sama dalam kelompok yang baik ditunjukkan ketika siswa saling membantu satu sama lain dalam menemukan data hasil pengamatan, saling memberi pendapat dan ikut adil dalam kegiatan pengamatan. Saling berdiskusi bersama kelompoknya, saling bertukar pikiran, menyatukan pendapat dalam mengisi tabel yang ada pada LKS. Sehingga mengemmbangkan keterampilan dalam bersikap kolaboratif antar anggota kelompok dalam memecahkan masalah yang ditemukan.

LKS dalam tahapan ini juga memberikan dampak yang baik bagi siswa memicu keterampilan berfikir menggali pengetahuan dalam mengklasifikasikan objek biologi yang diamati ke dalam sistem klasifikasi makhluk hidup. Dalam hal ini yaitu ketika siswa mampu mengelompokkan cacing tanah atau objek lain kedalam golongan tertentu. Pengklasifikasian ini ditunjukkan pada saat siswa mampu mengisi tabel yang tertuang di dalam LKS dengan tepat berdasarkan ciri atau karakteristik cacing tanah atau objek lain yang telah mereka peroleh dari kegiatan pengamatan yang di iringi dengan membaca buku pedoman. Hal tersebut sesuai dengan pernyataan Esler (dalam Tarjo: 2011) yang menyatakan bahwa keterampilan mengklasifikasi dikembangkan melalui latihan-latihan mengkategorikan benda-benda berdasarkan pada sifat-sifat benda tersebut dan suatu hasil klasifikasi yang cermat dan benar akan membantu pemahaman.

Setelah siswa melakukan kegiatan pengamatan dan telah mengisi LKS, maka dilakukan tahapan explanation yaitu siswa diwajibkan untuk mempresentasikan hasil pengamatannya dan berbagi pengetahuan dengan kelompok lainnya. Pada tahapan ini siswa mempunyai peluang untuk berlatih mengembangkan kerampilan menyampaikan perolehan hasil pengamatan yang sudah dituliskan pada LKS dalam bentuk lisan maupun gambar dalam slaide.

Selanjutnya dilakukan tahapan elaboration yaitu dilakukan kajian mengenai materi dunia hewan dikaitkan dengan salingtemas. Sehingga pengetahuan siswa dapat mengembangkan pengetahuannya dengan baik dan memiliki wawasan yang luas mengenai salingtemas. Pada tahapan akhir siklus dilakukan tahap evaluation bertujuan untuk mengetahui efektifitas tahap-tahap sebelumnya dan 
pengetahuan serta pemahaman konsep siswa.

Dengan demikian implementasi model learning cycle " $5 \mathrm{E}$ " dapat meningkatkan keterampilan proses sains yang pada dasarnya keterampilan proses sains ini sudah dimiliki oleh perserta didik.

\section{Hasil Belajar}

Hasil belajar siswa dapat diketahui setelah diberikan tes yaitu dengan memberikan tes ulangan harian yang diberikan pada setiap akhir siklus. Hal ini bertujuan untuk memperoleh gambaran sejauh mana siswa telah menguasai kompetensi dasar seperti yang telah dikembangkan dalam silabus.

Berdasarkan hasil tes diketahui bahwa persentase siswa yang mencapai KKM belajar dari prasurvei ke Siklus 1 mengalami peningkatan sebesar 52\%. Pada Siklus 1 persentase siswa yang mencapai KKM belajar hanya mencapai $71 \%$, persentase ini sudah mencapai target keberhasilan penelitian yaitu $\geq 70 \%$. agar siswa lebih memahami dan mengerti materi dan bukan hanya dihafal sebagai teori dam perolehan nilai hasil belajar yang lebih optimal, maka perlu dilakukan tindakan siklus 2. Pada Siklus II persentase siswa yang mencapai KKM belajar mencapai 75\%. Persentase tersebut mengalami peningkatan dari Siklus I sebesar $71 \%$. Persentase ini telah melebihi target keberhasilan penelitian yaitu $\geq 70 \%$.

Peningkatan hasil belajar ini juga ditunjukkan oleh peningkatan jumlah siswa yang telah mencapai KKM belajar.Peningkatan persentase tersebut dikarenakan pembelajaran yang dilakukan dengan model learning cycle “ $5 E$ ” Pada setiap pelaksanaan tahapannya (engagement, exploration, explanation, elaboration, dan evaluation) siswa siswa dapat mengembangkan sikap ilmiah, pebelajar dilibatkan secara aktif dalam proses pembelajaran sehingga siswa dapat bekerja sama, saling belajar, keakraban, saling menghargai, partisipasi, kemampuan berbahasa peserta didik, siswa lebih berpeluang untuk menyampaikan pendapat dan gagasan sehingga pengetahuan yang didapat lebih melekat dalam rangka memperoleh hasil belajar yang maksimal.

Dengan demikian menerapkan model learning cycle " $5 E$ " disertai LKS mengalami peningkatan hasil belajar siswa. Hal ini didukung dengan pernyataan Wibowo dkk (2010) " Terjadi peningkatan hasil belajar pada siswa kelompok eksperimen yang mengikuti pembelajaran TIK dengan model pembelajaran learning cycle " $5 E$ " dibandingkan dengan siswa kelompok kontrol yang menggunakan model pembelajaran konvensional".

\section{KESIMPULAN DAN SARAN Kesimpulan}

Berdasarkan analisis hasil penelitian tindakan kelas ini dapat disimpulkan bahwa mengimplementasikan model learning cycle " $5 E$ " disertai LKS dapat meningkatkan aktivitas, keterampilan proses sains, dan hasil belajar siswa. Hal ini berarti pembelajaran dengan model learning cycle “ $5 E$ " disertai LKS telah memberikan dampak positif terhadap peningkatan kualitas pembelajaran biologi, aktivitas belajar, dan keterampilan proses sains bagi siswa.

\section{Saran}

Pembelajaran dengan model learning cycle " $5 E$ " disertai LKS memiliki keunggulan, namun apabila akan memanfaatkan model ini disarankan untuk disesuaikan dengan materi yang akan dibelajarkan dan ketersediaan sarana dan prasarana yang diperlukan, karena tidak semua materi atau topik bahasan efektif untuk 
menggunakan model ini karena membutuhkan lebih banyak waktu dan prasarana dibanding pembelajaran konvensional.

\section{DAFTAR RUJUKAN}

Annonimus. 2011. Metode Pembelajaran Terbimbing. http://skripsigratis83.blogspot.com . Di akses pada tanggal 21 November 2011.

Gachy, Eliaz. 2011. Makalah Strategi Belajar Mengajar Kimia "Siklus Belajar 5e". http://egachy.blogspot.com.

Diakses pada tanggal 15 November 2011

Holil, Anwar. 2008. Keterampilan Proses.

http://anwarholil.blogspot.com diakses pada 22 Oktober 2011

Riduwan. 2005. Rumus dan Data dalam Analisis Stattistika. Bandung: Alfabeta

Rustaman, Nuryani. 2005. Strategi Belajar Mengajar Biologi. Malang: Alfabeta

Sardiman, A.M. 2006. Interaksi dan Motivasi Belajar Mengajar. Jakarta: PT. Raja Grafindo Persada

Suastika, Komang Gde. 2011. Implementasi Model Pembelajaran Siklus (Learning Cycle) Pada Pembelajaran Fisika Materi Dinamika Partikel Di Kelas $X$ Semester 1 SMA Negeri 1 Palangka Raya Tahun Ajaran 2010/2011. Yogyakarta: UNY

Sudjana, Anas. 2007. Pengantar Evaluasi Pendidikan. Jakarta: PT. Raja Grafindo Persada.

Tarjo. 2011. Jenis-jenis Keterampilan Proses Sains. http://tarjo- ajo.blogspot.com. Diakses 12 Mei 2012.

Wahyono, Rembun. 2000. Pembelajaran Konsep Reproduksi Tumbuhan Biji Dengan Pendekatan Keterampilan Proses Untuk Meningkatkan Hasil Belajar Siswa. Tesis: Tidak diterbitkan. PPS UPI Bandung : tidak diterbitkan.

Wibowo, Ari. 2010. Penerapan Model Pembelajaran Siklus Belajar (Learning Cycle) 5e dalam Meningkatkan Hasil Belajar Siswa Pada Matapelajaran Teknologi Informasi dan Komunikasi (Penelitian Kuasi Eksperimen terhadap Siswa Kelas VII SMPN 1 Lembang Tahun Ajaran 2009/2010). Bandung : UPI 